\title{
PENGARUH RELIGIUSITAS TERHADAP GRATITUDE PADA REMAJA YANG TINGGAL DI PANTI ASUHAN KRISTEN
}

\author{
Winny Agata, \\ Fransisca M. Sidabutar ${ }^{1}$ \\ Fakultas Psikologi \\ Universitas Pelita Harapan \\ Jl. MH. Thamrin Boulevard, Lippo Karawaci, \\ Tangerang 15811, Indonesia \\ Ie-mail:fransisca.sidabutar@uph.edu
}

\begin{abstract}
Adolescents who live in the orphanage usually don tive with their own family for a variety of reasons. Separation and disappointment with the family often make them hard to show gratitude. Previous studies show that there is a correlation between religiosity and gratitude. But even when they were educated in Christian orphanage that has a routine religious activity, many are found has a hard time to show his or her gratitude. By this research, author wanted to find out the influence of religiosity to gratitude, also the influence of each dimension of religiosity to gratitude. This study used The Four Basic Dimensions of Religiousness Scale and Gratitude Questionnaire - 6 Item Form. The participants of this study are 88 Christian adolescents who live at Christian orphanage, which are 11-20 years old. The result of this study shows that there is a significant influence of religiosity to gratitude $\left(\mathrm{R}^{2}=.176, p=.003\right)$, with the most significant influence of religiosity's dimension is behaving $(\mathrm{B}=.302, p=.019)$.
\end{abstract}

Keywords: religiosity; gratitude; adolescent; Christian; orphanage

\begin{abstract}
Abstrak-Remaja yang tinggal di panti asuhan umumnya tidak tinggal bersama keluarga mereka karena berbagai alasan. Perpisahan dan kekecewaan dengan keluarga seringkali membuat mereka sulit untuk menunjukkan gratitude. Penelitian-penelitian terdahulu menunjukkan adanya korelasi antara religiusitas dan gratitude. Namun walaupun mereka dididik dalam panti asuhan Kristen yang memiliki kegiatan keagamaan yang rutin serta aturan dan didikan yang disesuaikan dengan Alkitab, banyak pula yang masih sulit menunjukkan gratitude. Peneliti ingin mencari tahu bagaimana pengaruh gratitude, serta pengaruh dimensi-dimensi dalam religiusitas terhadap gratitude melalui penelitian ini. Penelitian ini menggunakan The Four Basic Dimensions of Religiousness Scale dan Gratitude Questionnaire - 6 Item Form. Partisipan dari penelitian ini adalah 88 remaja Kristen yang tinggal di panti asuhan Kristen, yang berumur 11-20 tahun. Hasil dari penelitian ini menunjukkan adanya pengaruh yang signifikan dari religiusitas terhadap gratitude $\left(\mathrm{R}^{2}=.176, p=.003\right)$. Tinjauan dari empat dimensi religiusitas, maka dimensi behaving menunjukkan pengaruh yang signifikan $(\mathrm{B}=.302, p=.019)$.
\end{abstract}

Kata kunci: religiusitas; gratitude; remaja; Kristen; panti asuhan 


\section{PENDAHULUAN}

Panti asuhan merupakan suatu tempat yang menunjukkan perhatian dan kepedulian terhadap anakanak yatim piatu ataupun anak-anak yang ditelantarkan (Zeanah, Smyke, \& Settles, dalam McCartney \& Philips, 2006).Anak-anak panti asuhan boleh jadi menemukan figur ayah atau ibu pada penguruspengurus panti asuhan. Namun demikian pada umumnya perhatian pengurus-pengurus panti tidak dapat dicurahkan sepenuhnya kepada mereka (Smyke, Koga, Johnson, Zeanah, \& the BEIP Core Group, dalam McCartney \& Philips, 2006). Musisi, Kinyada, Nakasujja, \& Nakigudde (2007) melaporkan bahwa anak-anak yang tinggal di panti asuhan merasa hidup tidak adil dibandingkan anak yang tinggal di rumah orangtua. Johnson (2014) menambahkan bahwa kondisi ini menyebabkan mereka tumbuh dengan kemarahan yang belum terselesaikan dan membuat mereka depresi serta kecewa.

Gratitude adalah rasa bersyukur dan terima kasih atas hal-hal dan kejadian yang telah terjadi dalam kehidupan seseorang (Seligman, Steen, Park, \& Peterson, dalam Mitchell, 2010). Gratitude juga dapat didefinisikan sebagai reaksi kognitif dan emosional yang timbul dari kesadaran atas apa yang telah dialami oleh seseorang yang kemudian menciptakan rasa berharga (Wood, Maltby, Stewart, \& Joseph, 2008).

Hal yang dirasakan oleh anak-anak panti asuhan, dimana mereka merasa beruntung masih dapat tinggal di panti asuhan dan mendapat perhatian dari para pengurus panti asuhan dapat juga disebut dengan gratitude.

McCullough, Emmons, dan Tsang (2002) mengatakan bahwa terdapat beberapa hal yang dapat mempengaruhi gratitude seseorang, antara lain adalah affect dan well-being, prosociality, dan spirituality. Peneliti memilih untuk fokus pada dimensi spirituality di penelitian ini berdasarkan fenomena yang ditemukan pada panti asuhan yang ingin diteliti, yaitu di salah satu panti asuhan Kristen. Di panti tersebut remaja yang tinggal di sana dididik dan dibina dengan ajaran Kristen dan terlibat dalam kegiatan keagamaan yang rutin, serta memiliki komunitas dimana mereka dapat berbagi dan bertumbuh bersama.

Spiritualitas didefinisikan sebagai persepsi yang timbul dari pengalaman seseorang, dimana keadaan atau kekuatan tersebut melampaui kesadaran dan kekuatan dirinya; hal ini tidak harus terjadi dalam konteks suatu agama yang terorganisir (Underwood \& Teresi, 2002). Konsep yang serupa dengan spiritualitas, yaitu religiusitas. Religiusitas adalah suatu keyakinan, praktek, serta ritual yang terkait dengan hubungan dengan Tuhan yang terjadi dalam konteks suatu agama yang terorganisir (King \& Benson, 2006). Namun kemudian, King dan Benson (2006) menyatakan bahwa perbedaan pada spiritualitas dan religiusitas tidaklah jelas karena konteks spiritualitas yang telah dijelaskan sebelumnya juga terjadi dalam konteks religiusitas, dimana religiusitas mendorong orang-orang untuk merasakan adanya kekuatan yang melampaui kesadaran dan kekuatan dirinya. Kirby, Coleman, dan Daley (2004) 
dalam penelitiannya juga menambahkan bahwa spiritualitas dan religiusitas sama-sama mengarah kepada suatu kepercayaan yang lebih tinggi, yaitu Tuhan. Oleh sebab itu pada penelitian ini, peneliti mengkonseptualisasikan spiritualitas dan religiusitas sebagai hal yang setara.

Religiusitas mengarahkan seseorang untuk menyadari bahwa apa yang terjadi pada mereka bukanlah suatu hal yang terjadi secara kebetulan, tetapi adalah suatu hal yang dikaruniakan kepada mereka, dan bukan diperoleh oleh kekuatan mereka sendiri (Emmons \& McCullough, 2004). Emmons (2012) menambahkan bahwa gratitude yang didasari oleh religiusitas adalah keadaan dimana seseorang menyadari bahwa ia tidaklah pantas, namun ia diberikan anugerah untuk menikmati keadaannya tersebut. Amin (2012) menyatakan bahwa semakin tinggi tingkat religiusitas seseorang, maka semakin tinggi juga tingkat gratitude seseorang. Pernyataan tersebut diperkuat dengan dua alasan, dimana semua agama dan kepercayaan menyatakan bahwa gratitude adalah suatu hal yang baik, serta gratitude akan tumbuh seiring dengan meningkatnya religiusitas, karena religiusitas mengarahkan seseorang mengenai bagaimana dirinya yang semula tidak pantas, namun diberikan karunia untuk menikmati kehidupannya.

Beberapa penelitian berusaha membuktikan adanya hubungan positif antara religiusitas dengan gratitude, di antaranya adalah penelitian yang dilakukan oleh Emmons \& McCullough (2004). Penelitian lainnya juga menunjukkan bahwa orang dengan tingkat religiusitas yang tinggi cenderung lebih sering menunjukkan gratitude dibanding orang dengan tingkat religiusitas yang rendah (Emmons \& Kneezel, 2005, dalam Emmons, 2012). Watkins, dkk (dalam Emmons, 2012) berpendapat bahwa gratitude merupakan ciri afektif positif yang terdapat dalam religiusitas. Dalam Alkitab, 1 Tesalonika 5: 18 menyatakan 'Mengucap syukurlah dalam segala hal, sebab itulah yang dikehendaki Allah di dalam Kristus Yesus bagi kamu juga mengajarkan bahwa Allah sendiri menghendaki manusia untuk selalu mengucap syukur dalam segala hal yang dialami. Berdasarkan penelitian-penelitian di atas, terlihat bila kehidupan religiusitas seseorang dapat mengarahkan dirinya kepada gratitude (Emmons \& McCullough, 2004).

Saroglou (2011) menyadari bahwa untuk penelitian psikologi, khususnya yang berhubungan dengan budaya, diperlukan adanya suatu alat ukur yang tidak hanya terbatas pada keunikan suatu agama tertentu ataupun hanya menekankan sisi teologis, namun juga bersifat universal. Saroglou mengidentifikasi empat komponen yang dapat dipakai untuk mengukur religiusitas, yaitu believing, bonding, behaving, dan belonging. Believing adalah kepercayaan akan adanya kekuatan transenden, yang melampaui kekuatan seseorang, namun tetap berhubungan dengan manusia dan dunia ini. Semua agama percaya dengan kondisi tersebut, bahkan pada agama yang tidak mempercayai keberadaan Tuhan, juga mengakui adanya kekuatan transenden (Atran \& Norenzayan, dalam Saroglou, 2011). Bonding lebih fokus kepada emosi yang dirasakan. Berkaitan dengan hal ini Saroglou (2011) menyatakan bahwa religiusitas bukan hanya sekedar suatu kepercayaan pada kekuatan transenden, tetapi juga pada pengalaman transenden yang dialami seseorang dengan kekuatan transenden yang diyakininya, yang dapat diperoleh melalui doa maupun meditasi. Behaving adalah standar-standar moral pada 
religiusitas, yang bukan hanya berkorelasi secara eksternal dengan religiusitas, namun merupakan dasar yang memberikan pandangan mengenai yang benar dan yang tidak benar (Saroglou, 2011). Belonging adalah keadaan dimana seseorang terkait di dalam sebuah kelompok atau komunitas, dimana mereka dapat merasakan adanya rasa kesatuan dan dianggap oleh sebuah kelompok atau komunitas (Saroglou, 2011). Berdasarkan landasan literatur yang didapatkan, penelitian ini bertujuan untuk mengetahui besar pengaruh religiusitas terhadap gratitude pada remaja Kristen yang tinggal di panti asuhan Kristen. Hipotesa penelitian ini adalah ada pengaruh yang signifikan dari religiusitas terhadap gratitude pada remaja Kristen yang tinggal di panti asuhan.

\section{METODE}

\section{Partisipan}

Populasi dalam penelitian ini adalah remaja yang tinggal di panti asuhan Kristen. Sedangkan sampel yang digunakan dalam penelitian ini adalah remaja Kristen yang berumur 11-20 tahun dan telah tinggal di panti asuhan Kristen di Pontianak selama minimal 1 tahun. Teknik sampling yang digunakan adalah purposive sampling, dimana sampel ditentukan dengan pertimbangan atas karakteristik dan ciriciri tertentu yang memiliki keterkaitan dengan populasi penelitian dan sesuai dengan tujuan penelitian (Purwanto, 2010).

Penentuan jumlah sampel berdasarkan pada jenis statistik yang digunakan, yaitu analisis regresi dan jumlah IV yang digunakan. Pada penelitian ini, jumlah IV yang digunakan ada 1, oleh sebab itu diperlukan sampel sebanyak minimal 20 sampel agar dapat dianalisis menggunakan analisis regresi (Tabachnick \& Fidell, 1985; dalam Green, 1991).

Penelitian ini kemudian menggunakan 88 remaja Kristen yang tinggal di panti asuhan Kristen dengan laki-laki berjumlah 35 orang (39.8\%) dan perempuan berjumlah 53 orang (60.2\%). Usia partisipan berkisar antara 11-20 tahun dengan rata-rata partisipan berusia 14 tahun $(M=14.89, S D=$ 2.092).

\section{Desain}

Penelitian ini menggunakan metode penelitian kuantitatif. Menurut Marczyk, DeMatteo, \& Festinger (2005), metode penelitian kuantitatif adalah sebuah metode penelitian yang menganalisa hasil penelitian dengan menggunakan metode statistik. Penelitian ini menggunakan metode penelitian kuantitatif karena variabel-variabel penelitian meruapakan variabel yang dapat diamati dan dapat diukur.

Penelitian ini adalah penelitian cross sectional, dimana penelitian hanya dilakukan sekali pada waktu yang telah ditentukan oleh peneliti untuk meneliti pengaruh variabel independen terhadap variabel dependen (Sugiyono, 2010). Variabel independen dari penelitian ini adalah religiusitas, 
sedangkan variabel dependen dari penelitian ini adalah gratitude. Teknik pengumpulan data dalam penelitian ini menggunakan kuesioner. Kuesioner merupakan teknik pengumpulan data yang efisien untuk mencari tahu mengenai variabel yang ingin diukur dan diteliti (Sugiyono, 2010). Penelitian ini ingin mengetahui seberapa besar pengaruh masing-masing dimensi religiusitas terhadap gratitude pada remaja yang tinggal di panti asuhan Kristen.

\section{Prosedur}

Peneliti menentukan metode penelitian yang akan digunakan serta mencari alat ukur yang akan digunakan dalam penelitian ini. Peneliti juga kemudian meminta bantuan para ahli untuk menerjemahkan alat ukur yang berbahasa Inggris menjadi bahasa Indonesia agar dapat dipahami oleh responden. Setelah diterjemahkan menjadi bahasa Indonesia, maka alat ukur tersebut akan diterjemahkan kembali ke bahasa Inggris untuk melihat apakah ada perbedaan makna setelah diterjemahkan.

Penelitian ini terlebih dahulu dilakukan uji coba kepada remaja dengan rentang umur 11-20 tahun sebelum kuesioner dibagikan kepada responden. Kriteria untuk menentukan suatu item valid atau tidak valid, dilakukan dengan menggunakan batas 0.2 pada kolom corrected item-total correlation, dimana apabila nilai korelasi berada di bawah 0.2, maka item dinyatakan tidak valid (Nisfiannoor, 2009). Hasil uji coba menunjukkan bahwa gratitude memiliki nilai Cronbach's Alpha.631 dengan corrected item-total correlation antara .041 -.696. Dimensi-dimensi religiusitas memiliki corrected item-total correlation antara .278 -.749. Berdasarkan hasil uji coba yang didapatkan dan dirasakan cukup, maka dilakukan pengambilan data lagi untuk penelitian yang sebenarnya kepada 88 partisipan.

Pencarian data dilakukan dengan cara membagikan kuesioner kepada partisipan yang termasuk dalam kategori sampel penelitian, yaitu remaja Kristen yang tinggal di panti asuhan Kristen. Sebelumnya peneliti akan menjelaskan terlebih dahulu apa yang harus dikerjakan oleh partisipan penelitian, seperti prosedur penelitian, informed consent, persetujuan partisipan untuk menjadi responden dalam penelitian, manfaat penelitian, dan kerahasiaan data partisipan sehingga partisipan dapat mengisi dengan bebas dan jujur tanpa harus takut apabila identitas dan jawabannya diketahui oleh pihak lain. Partisipan juga akan diminta untuk melengkapi data demografis, seperti usia, agama, dan jenis kelamin.

Partisipan melengkapi informed consent dan data demografis, partisipan akan mulai mengerjakan kuesioner. Partisipan akan terlebih dahulu diminta untuk mengerjakan Gratitude Questionnaire - 6 Item Form untuk menilai gratitude; bagian ini berisi 6 item. Sama seperti The Four Basic Dimensions of Religiousness Scale, partisipan juga akan diminta untuk memberikan 1 jawaban dari skor 1-7 (1= sangat tidak setuju dan $7=$ sangat setuju) dan jawaban ini diberikan berdasarkan keadaan yang paling menggambarkan partisipan. Selanjutnya partisipan akan diminta untuk mengerjakan The Four Basic Dimensions of Religiousness Scale untuk menilai spiritualitas/religiusitas; bagian ini berisi 12 item. Partisipan akan diminta untuk memberikan 1 jawaban dari skor 1-7 (1= sangat tidak setuju dan $7=$ sangat setuju) dan jawaban ini diberikan berdasarkan keadaan yang paling menggambarkan partisipan. 


\section{Teknik Analisis}

Peneliti terlebih dahulu menganalisis apakah data yang didapatkan memiliki sebaran data yang normal atau tidak. Untuk menguji kenormalan penyebaran data, maka peneliti akan menggunakan uji normalitas Kolgomorov Smirnov. Peneliti kemudian akan menguji korelasi dengan Pearson Product Moment untuk mengidentifikasi seberapa besar hubungan yang terjadi antara variabel. Penelitian ini menggunakan metode statistik regresi dengan bantuan SPSS. Pemilihan metode statistik ini dikarenakan oleh tujuan penelitian untuk melihat pengaruh variabel independen terhadap variabel dependen (Sarwono, 2012).

\section{ANALISIS DAN HASIL}

Peneliti melakukan pengujian normalitas, validitas, dan reliabilitas setelah pengambilan data selesai dilakukan. Peneliti menggunakan Kolgomorov-Smirnov dengan nilai signifikansi p >.05, dan dalam penelitian ini, gratitude, believing, bonding, behaving, dan belonging memiliki distribusi normal (Raharjo, 2013).

Gratitude memiliki nilai Cronbach's Alpha $(\alpha)=.616$ dengan corrected item-total correlation antara .253 -.602. Believing memiliki nilai Cronbach's Alpha $(\alpha)=.421$ dengan corrected item-total correlation antara $.236-.289$, bonding memiliki nilai Cronbach's Alpha $(\alpha)=.381$ dengan corrected item-total correlation antara 197 -.279, behaving memiliki nilai Cronbach's Alpha $(\alpha)=.478$ dengan corrected item-total correlation antara .284 -.335, dan belonging memiliki nilai Cronbach's Alpha $(\alpha)$ $=.665$ dengan corrected item-total correlation antara $.375-.596$. Hal ini menunjukkan bahwa semua item dalam penelitian ini valid dan reliabel.

Tabel 1.

Statistik Deskriptif Believing, Bonding, Behaving, Belonging

\begin{tabular}{ccccc}
\hline & Min & Max & Mean & Std. Deviation \\
\hline Believing & 11.00 & 21.00 & 18.114 & 2.507 \\
Bonding & 8.00 & 21.00 & 16.250 & 2.705 \\
Behaving & 11.00 & 21.00 & 17.600 & 2.504 \\
Belonging & 11.00 & 21.00 & 17.022 & 2.881 \\
\hline
\end{tabular}

Tabel 1 menggambarkan analisis deskriptif untuk dimensi believing, bonding, behaving dan belonging, yang masing-masing memiliki kisaran nilai antara 11-20, 8-20, 11-20, dan 11-20. Semakin tinggi skor yang dihasilkan menunjukkan semakin tinggi pula dimensi tersebut pada diri seseorang. Berdasarkan hasil pengukuran. gratitude memiliki kisaran nilai total antara 12-28, yang juga berarti bahwa semakin tinggi nilai skor yang dihasilkan maka semakin tinggi pula nilai gratitude pada diri seseorang. Tingkat religiusitas dan gratitude responden umumnya di atas rata-rata. 
Hasil uji regresi yang tampak pada tabel 2 menunjukkan adanya pengaruh yang signifikan dari religiusitas terhadap gratitude pada remaja yang tinggal di panti asuhan $\operatorname{Kristen}\left(\mathrm{R}^{2}=.176, p=.003\right)$. Hasilnya menunjukkan bahwa variabel religiusitas menjelaskan sekitar $18 \%$ varians gratitude $\left(R^{2}=\right.$ $.176, F=4.435, p=.003), 82 \%$ varians dijelaskan oleh faktor-faktor lain di luar keempat dimensi religiusitas. Karena nilai $p<.05$, maka $\mathrm{H} 0$ ditolak.

Penelitian ini juga melakukan beberapa analisis tambahan seperti pengaruh dimensi religiusitas terhadap gratitude dan juga perbedaan kedua variabel berdasarkan data demografis.

Tabel 2.

Uji Multiple Regression

\begin{tabular}{cccccc}
\hline Model & \multicolumn{2}{c}{$\begin{array}{c}\text { Unstandardized } \\
\text { Coefficients }\end{array}$} & $\begin{array}{c}\text { Standardized } \\
\text { Coefficients }\end{array}$ & T & Sig. \\
& B & Std. Error & & & \\
\hline (Constant) & 14.360 & 2.599 & & 5.525 & .000 \\
Belonging & .104 & .117 & .107 & .890 & .376 \\
Behaving & .302 & .126 & .270 & 2.394 & .019 \\
Bonding & .177 & .118 & .171 & 1.504 & .136 \\
Believing & -.023 & .123 & -.020 & -.184 & .854 \\
\hline
\end{tabular}

Tabel 2 menunjukkan uji multiple regression untuk melihat mana dari keempat dimensi religiusitas, yaitu dimensi believing, bonding, behaving, dan belonging yang memberikan pengaruh yang signifikan terhadap gratitude. Berdasarkan hasil multiple regression, ditemukan bahwa dimensi yang memberikan pengaruh yang signifikan adalah behaving $(\mathrm{B}=.302, p=.019)$, sedangkan dimensi bonding $(\mathrm{B}=.177, p=.136)$, belonging $(\mathrm{B}=.104, p=.376)$, dan believing $(\mathrm{B}=-.023, p=.854)$ tidak memberikan pengaruh yang signifikan.

Perbedaan religiusitas dan gratitude pada responden juga dianalisis berdasarkan rentang usia. Menurut Gay \& Diehl (1992), minimal sampel untuk perbandingan adalah 30 responden per kelompok. Adanya perbandingan responden yang tidak seimbang antara masing-masing rentang usia menyebabkan penyebaran data yang tidak normal, sehingga analisis rentang usia menggunakan uji analisis non-parametrik. Hasil perhitungan dengan rumus Kruskal-Wallis menunjukkan bahwa ada perbedaan yang signifikan pada religiusitas remaja awal, remaja tengah, dan remaja akhir $(p=.000)$, dengan remaja awal menunjukkan tingkat religiusitas tertinggi $(M=55.88)$, diikuti remaja akhir $(M=$ 46.29), dan remaja tengah $(M=24.23)$. Tidak ada perbedaan signifikan yang ditemukan pada gratitude remaja awal, remaja tengah, dan remaja akhir $(p=.119)$. Hal ini berarti tingkat religiusitas seseorang dipengaruhi oleh rentang usianya.

Selanjutnya perbedaan religiusitas dan gratitude pada responden berdasarkan jenis kelamin juga diuji perbedaannya. Hasil uji t-test menunjukkan bahwa tidak ada perbedaan yang signifikan pada religiusitas laki-laki dan perempuan $(F=.117, p=.826)$. Namun ada perbedaan yang signifikan 
pada gratitude laki-laki dan perempuan $(F=1.078, p=.039)$, dengan tingkat gratitude perempuan lebih tinggi $(M=24.40, S D=2.582)$ daripada laki-laki $(M=23.14, S D=2.962)$. Hal ini berarti tingkat gratitude seseorang dipengaruhi oleh jenis kelamin.

\section{DISKUSI}

Hipotesa yang ingin diuji dalam hal ini adalah ada atau tidaknya pengaruh yang signifikan dari religiusitas terhadap gratitude. Sebelum melakukan uji regresi untuk mendapatkan jawaban dari hipotesa yang dibuat, maka terlebih dahulu dilakukan uji korelasi Pearson. Hasil penelitian menunjukkan bahwa religiusitas memiliki korelasi yang signifikan dengan gratitude $(r=.383, p=.000)$. Hasil tersebut sesuai dengan yang dikatakan oleh Emmons, McCullough (dalam Emmons, 2012), \& Kneezel (dalam Emmons, 2012) bahwa religiusitas memiliki hubungan yang positif dengan gratitude. Dimensi-dimensi dari religiusitas juga menunjukkan korelasi yang signifikan dengan gratitude, seperti bonding ( $r=.296$, $p=.005)$, behaving $(r=.361, p=.001)$, dan belonging $(r=.290, p=.006)$, kecuali believing $(r=.159$, $p=.138$ ) tidak memiliki korelasi yang signifikan dengan gratitude.

Setelah didapatkan nilai korelasi kedua variabel, maka dilakukan analisis multiple regression dan didapatkan bahwa religiusitas berpengaruh secara signifikan terhadap gratitude $\left(R^{2}=.176, p=\right.$ .003). Hal ini menunjukkan bahwa dimensi-dimensi religiusitas, yaitu believing, bonding, behaving, dan belonging secara bersama-sama menjelaskan sekitar 18\% varians gratitude. Hasil tersebut sesuai dengan penelitian McCullough, Emmons, dan Tsang (2002) yang menyatakan bahwa religiusitas berpengaruh terhadap gratitude seseorang, karena lewat religiusitas seseorang menjadi sadar bahwa apa yang terjadi dalam kehidupan mereka bukanlah hal yang terjadi secara kebetulan ataupun usaha mereka sendiri, melainkan suatu hal yang dikaruniakan kepadanya (Emmons \& McCullough, 2004). Seseorang kemudian menjadi sadar bahwa ia sebenarnya tidak pantas untuk menerima apa yang terjadi dalam kehidupannya, namun ia diberikan anugerah untuk menikmati keadaan tersebut (Emmons, 2012). Remaja di panti asuhan seringkali memiliki pandangan yang berbeda terhadap hidup yang mereka jalani. Ada yang merasa kecewa dan marah dengan kenyataan hidup mereka, tetapi ada juga yang bersyukur dengan keadaan bahwa masih ada pihak yang mau merawat, mendidik, dan memperhatikan mereka. Selain itu, religiusitas juga mengarahkan penyelesaian masalah seseorang sehingga ia dapat mempunyai pandangan yang lebih positif, yang kemudian mengarahkan seseorang untuk mengalami emosi-emosi yang lebih positif.

Hasil uji multiple regression menunjukkan bahwa dimensi behaving menunjukkan pengaruh yang signifikan terhadap gratitude $(\mathrm{B}=.302, p=.019)$. Menurut Saroglou (2012), dimensi behaving seseorang mempengaruhi seseorang untuk mempunyai pandangan yang lebih positif dalam kehidupannya. Selain itu, dimensi behaving juga fokus pada perilaku prososial, dimana remaja panti asuhan mendapatkan 
bantuan, baik berupa sumbangan materi maupun perhatian dari para donatur. Para remaja kemudian akan menyadari bahwa kebaikan dan kesejahteraan yang dialaminya adalah hasil kontribusi dari pihak lain, yang sekaligus akan memotivasinya untuk berbuat seperti demikian juga bagi pihak lain (McCullough, Kilpatrick, Emmons, \& Larson, 2001 dalam McCullough, Emmons, \& Tsang, 2002). Kepekaan terhadap hal tersebut akhirnya akan mengarahkan seseorang untuk lebih bersyukur (Steffen \& Masters, 2005 dalam Saroglou, 2011).

Penelitian ini juga ingin melihat besar pengaruh dari masing-masing dimensi religiusitas selain pengaruh religiusitas secara total, maka ditemukan bahwa dimensi behaving memiliki pengaruh yang signifikan terhadap gratitude $(\beta=.302, p=.019)$. Ketiga dimensi lainnya dari religiusitas, yaitu dimensi believing, bonding, dan belonging masing-masing tidak menunjukkan pengaruh yang signifikan terhadap gratitude $(\beta=.177, p=.136 ; \beta=-.023, p=.854$; dan $\beta=.104, p=.376)$. Pengaruh $18 \%$ (dari total $100 \%$ ) terlihat tidak begitu besar dan hal ini sesuai dengan pernyataan Emmons (2012), yang menyatakan bahwa religiusitas dan gratitude memang menunjukkan hubungan yang positif, walaupun dengan nilai korelasi yang tidak begitu besar $(r=.28-r=.52)$.

Behaving menunjukkan pengaruh yang signifikan terhadap gratitude $(r=.361, p=.001)$. Dimensi behaving memberikan batasan-batasan moral mengenai kontrol diri dan kehidupan yang bermoral, begitu juga dengan perilaku prososial dan manfaatnya. Menurut Fowler (dalam Roehlkepartain, King, Wagener, \& Benson, 2006), remaja mengembangkan kepercayaan dan nilai-nilai dalam hidup mereka dengan melakukan konformitas pada orang-orang terdekat mereka, karena pada tingkatan iman yang awal, seseorang akan memandang Tuhan dan agama sebagai suatu bentuk yang konkrit dan mengikuti nilai yang dianut oleh agama tanpa mempertanyakan lebih lanjut. Pada masa tersebut remaja sedang berada pada tahapan synthetic-conventional faith, dimana remaja berusaha melakukan konformitas dengan orang-orang terdekat, yang dalam penelitian ini adalah para pengurus panti asuhan. Pengurus panti asuhan mendidik dan mengajar para remaja tersebut dengan aturan-aturan yang sesuai dengan Tuhan (menurut Alkitab). Pengurus panti asuhan juga mengajarkan mereka untuk mengucapkan syukur dan terima kasih kepada para donatur yang telah menyumbangkan materi maupun perhatian kepada mereka. Dengan demikian, para remaja panti asuhan menerapkan aturan-aturan yang diberikan pada mereka oleh para pengurus panti asuhan, sehingga secara tidak langsung mereka mengembangkan dimensi behaving dan gratitude dalam diri mereka.

Hasil penelitian juga menemukan bahwa ketiga dimensi religiusitas lainnya tidak menunjukkan pengaruh yang signifikan terhadap gratitude. Dimensi believing memiliki korelasi yang positif terhadap gratitude namun tidak memiliki korelasi yang signifikan $(r=.159, p=.138 ; \mathrm{B}=.177, p=.136)$. Dimensi believing membantu seseorang untuk menemukan arti dan mengerti tujuan dari kehidupannya (Park, 2005 dalam Saroglou, 2011). Namun, Berk (2008) menyatakan bahwa religiusitas yang mengarah pada penemuan arti dan tujuan hidup lebih berpengaruh pada remaja akhir; sedangkan dalam penelitian ini, responden yang dapat dikategorikan sebagai remaja akhir (18-20 tahun) hanya sebesar 14\% dari total 
responden. Oleh sebab itu, dimensi believing tidak menunjukkan adanya pengaruh karena kebanyakan responden belum terlalu memperhatikan aspek tersebut dalam kehidupannya.

Dimensi bonding memiliki korelasi yang positif, namun tidak berpengaruh secara signifikan terhadap gratitude $(r=.296, p=.005 ; \mathrm{B}=-.023, p=.854)$. Dimensi bonding memberikan seseorang emosi-emosi positif, rasa aman, dan juga pengontrolan emosi-emosi negatif yang didapatkan melalui hubungan antara seseorang dengan kekuatan transenden yang diyakininya (Fredrickson, 2002 dalam Saroglou, 2011). McCullough, Emmons, dan Tsang (2002) menyatakan bahwa seseorang yang sering mengalami emosi positif cenderung akan lebih sering menunjukkan gratitude, karena emosi positif adalah dasar seseorang untuk menunjukkan rasa bersyukur. Namun, dimensi bonding tidak menunjukkan pengaruh yang signifikan, hal ini mungkin dipengaruhi oleh tingkatan iman yang dijelaskan oleh Fowler (dalam Roehlkepartain, King, Wagener, \& Benson, 2006), dimana tidak semua orang bisa mencapai tingkatan iman dimana ia dapat merefleksikan apa yang ia rasakan berdasarkan keyakinan dan nilai yang dianut oleh agamanya (tingkat individual-reflective faith), sehingga belum tentu semua remaja di panti asuhan tersebut dapat merasakan hal demikian

Begitu juga dengan dimensi belonging yang memiliki korelasi yang positif ( $r=.290, p=.006$; $\mathrm{B}=.104, p=.376)$. Dimensi belonging memberikan seseorang dukungan sosial, rasa diperhatikan dan memiliki, dan juga mengembangkan harga diri, dimana seseorang merasa ada pihak lain yang turut peduli dengan apa yang dialaminya dan ada dukungan serta perhatian yang diberikan oleh kelompok/komunitasnya (Greenfield \& Marks, dalam Saroglou, 2011). Namun, dimensi belonging tidak menunjukkan pengaruh yang signifikan, hal ini mungkin dipengaruhi oleh kecenderungan remaja untuk melakukan konformitas kepercayaan dan nilai-nilai dalam hidup mereka dengan orang-orang terdekat mereka, dalam hal ini adalah para penghuni panti lainnya, sehingga rasa belonging kurang terasa dan hanya dianggap sebagai suatu bentuk konformitas (Fowler, dalam Roehlkepartain, King, Wagener, \& Benson, 2006).

Ketiga dimensi yang tidak memiliki pengaruh yang signifikan terhadap gratitude ini menunjukkan adanya persamaan, yaitu dimensi believing, bonding, dan belonging sama-sama berfokus pada halhal yang reflektif, yang berkaitan dengan perasaan masing-masing individu. Berbeda dengan dimensi behaving yang berfokus pada hal-hal yang konkrit, yaitu mengenai batasan-batasan moral mengenai kontrol diri dan kehidupan yang bermoral. Oleh karena itu, dapat disimpulkan bahwa bentuk religiusitas dan gratitude yang ditunjukkan oleh para remaja panti asuhan tersebut hanyalah sebuah bentuk konformitas terhadap aturan yang diberikan oleh pengurus panti asuhan. Hal ini kemudian didukung oleh pernyataan Fowler (dalam Roehlkepartain, King, Wagener, \& Benson, 2006) yang menyatakan bahwa tidak semua orang bisa mencapai tingkatan iman dimana ia dapat merefleksikan apa yang ia rasakan berdasarkan keyakinan dan nilai yang dianut oleh agamanya (tingkat individual-reflective faith). Fowler juga menambahkan bahwa pada tingkatan iman yang awal, seseorang akan memandang 
Tuhan dan agama sebagai suatu bentuk yang konkrit dan mengikuti nilai yang dianut oleh agama tanpa mempertanyakan lebih lanjut.

Hal ini kemudian sesuai dengan penelitian-penelitian religiusitas dan gratitude yang dilakukan terdahulu juga ditemukan adanya korelasi yang kecil $(r=.28-r=.52)$. Menurut Berk (2008), religiusitas seringkali lebih berpengaruh pada masa remaja akhir, dimana mereka mulai mencari arti dan tujuan hidup. Pada penelitian ini, partisipan penelitian rata-rata berusia 14 tahun (remaja tengah). Oleh sebab itu, hal ini dapat menjadi sebab mengapa religiusitas terlihat kurang berpengaruh pada remaja di panti asuhan tersebut. Penelitian yang dilakukan oleh Emmons \& McCullough (2004), juga menemukan adanya korelasi antara spiritualitas \& religiusitas dengan gratitude berkisar antara $r=.14-r=.29$. Pada penelitian tersebut, Emmons \& McCullough menggunakan STS (Spiritual Transendence Scale) yang itemnya memiliki kesamaan dengan item 4BDRS (The Four Basic Dimensions of Religiousness Scale) pada dimensi believing, bonding, dan belonging (Contoh: I believe that there is a larger meaning to life = item dimensi believing; I meditate and/or pray so that I can reach a higher spiritual plane of consciousness = item dimensi bonding; It is important for me to give something back to my community = item dimensi belonging).

Hasil analisis memperlihatkan bahwa tidak terdapat perbedaan yang signifikan untuk religiusitas berdasarkan jenis kelamin $(F=.049, p=.826)$. Namun hasil analisis memperlihatkan bahwa terdapat perbedaan yang signifikan untuk religiusitas berdasarkan usia $(F=.036, p=.965)$. Hasil penelitian menunjukkan bahwa remaja awal memiliki religiusitas yang paling tinggi $(M=55.88)$, diikuti oleh remaja akhir $(M=46.29)$, dan remaja tengah $(M=24.23)$. Hal ini bertentangan dengan pendapat Berk (2008) yang menyatakan bahwa remaja awal seringkali menunjukkan tingkat religiusitas yang rendah dalam kehidupan karena adanya keinginan dari diri remaja untuk lebih mandiri dan mengembangkan autonomy. Granqvist \& Dickie (1999, dalam Roehlkepartain, King, Wagener, \& Benson, 2006) juga menambahkan bahwa remaja cenderung menuntut autonomy, namun belum dapat melepaskan diri dari pengawasan orang tua. Dalam hal ini, remaja panti asuhan tentunya juga sulit untuk melepaskan diri dari pengawasan para pengurus panti asuhan, ditambah dengan kehidupan di panti asuhan yang diatur menurut aturan dan jadwal yang ditetapkan oleh pengurus panti asuhan. Hal ini juga kemudian menyebabkan ketidakjelasan pada hubungan seorang remaja dengan Tuhan, karena seseorang dapat mengembangkan kedekatannya dengan Tuhan atau justru menjauhi Tuhan.

Selain itu, menurut Fowler (1981, dalam Fowler, 2009) ada beberapa tingkatan iman pada remaja dan hal ini tidak ditentukan oleh usia remaja tersebut karena tingkatan iman ini berbeda-beda pada setiap orang. Terdapat tingkatan primal faith hingga universalizing faith, dan berbagai tingkatan tersebut berkembang sesuai dengan pengenalan seseorang terhadap Tuhan yang diyakininya sehingga hal tersebut tentunya berbeda-beda dalam setiap individu. Berdasarkan penjelasan tersebut, maka dapat disimpulkan bahwa tingkatan iman seseorang tidak berdasarkan usia, melainkan berdasarkan perkembangan iman yang dialami oleh masing-masing orang. 
Hasil analisis memperlihatkan bahwa tidak terdapat perbedaan yang signifikan untuk gratitude berdasarkan usia $(F=.799, p=.453)$. Namun hasil analisis memperlihatkan bahwa terdapat perbedaan yang signifikan untuk gratitude berdasarkan jenis kelamin $(F=1.078, p=.039)$, dimana remaja perempuan memiliki gratitude yang lebih tinggi $(M=24.40, S D=2.582)$ dibandingkan remaja lakilaki. Menurut Fujita, Diener, \& Sandvik (dalam Kashdan, Mishra, Breen, \& Froh, 2009), perempuan diyakini lebih mengekspresikan berbagai emosi yang dirasakannya dibanding laki-laki. Perempuan lebih memahami dan mengerti emosi yang dirasakannya dibandingkan dengan laki-laki (Barrett, Lane, Sechrest, \& Schwartz, 2000, dalam Kashdan, Mishra, Breen, \& Froh, 2009). Oleh sebab itu, wanita juga lebih dapat mengekspresikan gratitude yang ia alami di dalam hidupnya (Timmers, dkk, dalam Kashdan, Mishra, Breen, \& Froh, 2009).

\section{SIMPULAN DAN SARAN}

Penelitian ini bertujuan untuk melihat besar pengaruh masing-masing dimensi religiusitas, yaitu believing, bonding, behaving, dan belonging terhadap gratitude. Berdasarkan penelitian yang dilakukan terhadap 88 remaja panti asuhan Kristen di Pontianak, didapatkan kesimpulan bahwa religiusitas mempunyai pengaruh yang signifikan terhadap gratitude dan menjelaskan 14\% varians gratitude, dimana sisanya dipengaruhi oleh faktor-faktor lain di luar variabel.

Terdapat pengaruh yang signifikan dari dimensi behaving terhadap gratitude. Hal ini menunjukkan semakin tinggi nilai behaving dalam diri seseorang berarti semakin tinggi pula gratitude dalam dirinya. Begitu pula sebaliknya, semakin rendah nilai behaving dalam diri seseorang berarti semakin rendah pula gratitude dalam dirinya.

Hasil analisis tambahan menunjukkan bahwa tidak terdapat perbedaan yang signifikan untuk gratitude pada remaja awal, remaja tengah, dan remaja akhir. Namun terdapat perbedaan yang signifikan untuk religiusitas pada remaja awal, remaja tengah, dan remaja akhir. Hal ini berarti rentang usia remaja memberikan pengaruh terhadap tingkat religiusitas. Namun hal ini tetap bergantung pada tingkatan iman pada masing-masing orang.

Begitu juga dengan jenis kelamin, tidak terdapat perbedaan yang signifikan untuk religiusitas pada remaja laki-laki dan perempuan. Namun terdapat perbedaan yang signifikan untuk gratitude pada remaja laki-laki dan perempuan. Hal ini berarti jenis kelamin memberikan pengaruh terhadap tingkat gratitude. Perempuan lebih dapat mengekspresikan emosi positif yang dialaminya dibandingkan lakilaki.

Kesimpulan ini hanya berlaku untuk remaja Kristen di panti asuhan Kristen yang berusia antara 11-20 tahun. 
Dari hasil penelitian ini didapatkan bahwa pengaruh religiusitas terhadap gratitude hanya sebesar $18 \%$, dengan dimensi behaving ditemukan paling berpengaruh terhadap gratitude. Oleh sebab itu, dalam penelitian selanjutnya peneliti dapat menambahkan faktor lain yang dapat mempengaruhi gratitude yang berhubungan dengan behaving dan juga mengenai tingkat konformitas pada masa remaja.

Hasil penelitian ini juga menunjukkan adanya korelasi yang positif antara masing-masing dimensi religiusitas, yaitu believing, bonding, behaving, dan belonging terhadap gratitude. Namun remaja yang dijadikan responden hanyalah remaja panti asuhan Kristen pada umumnya. Oleh sebab itu, dalam penelitian selanjutnya peneliti dapat memilih responden remaja non panti asuhan yang memiliki kegiatan atau komunitas keagamaan yang lebih luas dibandingkan remaja panti asuhan.

Saran bagi para remaja panti asuhan, diharapkan dapat lebih mengerti dan memahami agama dan Tuhan yang diyakininya, baik melalui pembelajaran agama, relasi pribadi, maupun relasi dengan komunitas agama. Selain itu, para remaja panti asuhan juga dapat menerapkan doa syafaat untuk sesama penghuni panti asuhan, sehingga dapat belajar untuk lebih peduli dengan sesamanya. Hal ini dikarenakan oleh adanya korelasi yang positif bahkan signifikan antara religiusitas terhadap gratitude yang mempunyai banyak manfaat dalam kehidupan, khususnya dalam upaya membantu remaja untuk mengembangkan emosi-emosi positif dan juga pencarian identitas diri.

Bagi pengurus panti asuhan juga diharapkan dapat memperhatikan religiusitas para remaja panti asuhan, seperti ketika sedang melakukan pembelajaran agama dalam komunitas, maupun relasi antara pengurus panti asuhan dengan remaja dengan mengaplikasikan nilai-nilai yang terdapat pada agama Kristen. Khususnya mereka yang sedang menuju tahapan remaja akhir, religiusitas berperan penting dalam membantu para remaja untuk menemukan identitas diri dan arti hidupnya. Selain itu, religiusitas juga membantu para remaja untuk hidup lebih bermoral dan tentunya akan membantu mereka untuk menghindari hal-hal yang negatif.

Pengurus panti asuhan harus memperhatikan bahwa tingkat konformitas pada remaja sangat tinggi, sehingga perlu diperhatikan mengenai kegiatan-kegiatan para remaja panti asuhan, misalnya seperti mengikutkan para remaja panti asuhan dalam kegiatan keagamaan di luar panti asuhan, sehingga religiusitas dan gratitude para remaja panti asuhan bukan hanya sekedar konformitas terhadap peraturan yang diterapkan di panti asuhan.

Pengurus panti asuhan juga dapat mengajak para remaja panti asuhan untuk bergabung dengan komunitas agama Kristen di luar panti asuhan, sehingga lingkup komunitas tidak hanya beranggotakan penghuni panti, melainkan juga teman-teman sebaya di luar panti asuhan, sehingga para remaja dapat mengembangkan rasa belonging, dimana remaja panti asuhan tidak hanya merasa diperhatikan oleh teman-teman sebayanya yang senasib dengannya, tetapi juga oleh masyarakat luar. Selain itu, pengurus panti juga dapat menerapkan proyek ketaatan untuk para remaja panti asuhan. Dengan demikian, hal tersebut dapat mengembangkan prosociality dalam diri mereka, karena mereka merasa diperhatikan 
dan dipedulikan sehingga dapat mendorong mereka juga untuk memperhatikan orang-orang lain yang memerlukan.

Bagi konselor dan tenaga sosial yang berhubungan dengan remaja panti asuhan diharapkan dapat lebih memperhatikan berbagai hal yang berhubungan dengan religiusitas mereka, khususnya untuk bonding, behaving, dan belonging yang memiliki pengaruh yang sangat penting pada gratitude. Begitu juga untuk believing yang berperan penting pada saat remaja mulai mencari identitas diri dan arti hidupnya. Serta mengingat jumlah pengurus panti asuhan yang seringkali jumlahnya tidak seimbang dengan penghuni panti asuhan, maka perlu adanya bantuan perhatian khusus, karena masa remaja merupakan masa yang sangat penting dan berpengaruh dalam kehidupan seseorang. Para konselor dan tenaga sosial juga harus memperhatikan cara untuk membantu para remaja panti asuhan untuk mengungkapkan perasaan atau rasa ingin tahu mereka mengenai religiusitas dan gratitude (misalnya dalam kelompok-kelompok kecil sehingga para remaja lebih bebas mengungkapkan perasaan), sehingga mereka dapat benar-benar mengerti dan menerapkannya dan bukan hanya sekedar bentuk konformitas terhadap aturan panti asuhan.

\section{REFERENSI}

Amin, A. (2012). The 31 Benefits of Gratitude You Didn't Know About: How Gratitude Can Change Your Life. Ditemu kembali dari http://happierhuman.com/benefits-of-gratitude

Berk, L. E. (2008). Infants, Children, and Adolescents, (6th edition). Boston, MA: Pearson Education.

Emmons, R. A. (2007). Thanks!: How the New Science of Gratitude Can Make You Happier. New York, NY: Houghton Mifflin Company. (2010). Why Gratitude is Good. Ditemu kembali dari http://greatergood.berkeley.edu/ article/item/why_gratitude_is_good

. (2012). Queen of The Virtues? Gratitude as a Human Strength. Ditemu kembali darihttp:// journals.sfu.ca/rpfs/index.php/rpfs/article/viewFile/59/58

Emmons, R. A., \& McCullough, M. E. (2004). The Psychology of Gratitude. New York, NY: Oxford University Press.

Fowler, J. W. (2009). The Stages of Faith. Ditemu kembali dari https: //www.integrallife.com/ node $/ 40372$

Gay, L.R., \& Diehl, P. L. (1992). Research Methods for Business and Management. New York, NY: Macmillan Publishing.

Green, S. B. (1991). How many subjects does it take to do a regression analysis?.Mulitivariate Behavioral Research, 26(3), 499-510 
Johnson, W. D. (2014). The Effects of Being an Orphan. Ditemu kembali dari http://www.ehow.com/ info_8152695_effects-being-orphan.html

Kashdan, T.B., Mishra, A., Breen, W. E., \& Froh, J. J. (2009). Gender differences in gratitude: Examining appraisals, narratives, the willingness to express emotions, and changes in psychological needs. Journal of Personality, 77(3), 1-40.

King, P., \& Benson, P. L. (2006). Spiritual development and adolescent well-being and thriving. The Handbook of Spiritual Development in Childhood and Adolescence. New York, NY: Sage.

Kirby, S. E., Coleman, P. G., \& Daley, D. (2004). Spirituality and well-being in frail and nonfrail older adults. Journal of Gerontology, Psychological Sciences, 59B(3), 123-129.

Marczyk, G., DeMatteo, D., \& Festinger, D. (2005). Essentials of Research Design and Methodology. River Street Hoboken, NJ: John Wiley \& Sons.

McCartney, K., \& Philips, D. (2006). Blackwell Handbook of Early Childhood Development. Malden, MA: Blackwell Publishing.

McCullough, M. E., Emmons, R. A., \& Tsang, J. A. (2002). The grateful disposition: A conceptual and empirical topography. Journal of Personality and Social Psychology, 82, 112-127.

Mitchell, R. A. (2010). Thankful couples: Examining gratitude and marital happiness at the dyadic level. University of North Carolina Wilmington in Partial Fulfillment, USA.

Musisi, S., Kinyanda, E., Nakasujja, N., \& Nakigudde, J. (2007). A comparison of the behavioral and emotional disorders of primary school-going orphans and non-orphans in Uganda. African Health Sciences, 7(4), 202-213.

Nisfiannoor, M. (2009). Pendekatan Statitiska Modern: Untuk Ilmu Sosial. Jakarta: Salemba Humanika. Purwanto. (2010). Metodologi Penelitian Kuantitatif untuk Psikologi dan Pendidikan. Yogyakarta: Pustaka Pelajar.

Raharjo, S. (2013). Uji Normalitas Rumus Kolmogorov-Smirnov SPSS. Ditemu kembali dari http:// www.konsistensi.com/2013/07/uji-normalitas-rumus-kolmogorov-smirnov.html

Roehlkepartain, E. C., King, P. E., Wagener, L., \& Benson, P. L. (2006). The handbook of spiritual development in childhood and adolescence. Thousand Oaks, CA: Sage Publications.

Saroglou, V. (2011). Believing, bonding, behaving, and belonging: The big four religious dimensions and cultural variations. Journal of Cross-Cultural Psychology, 42(8), 1320-1340.

Saroglou, V., Buxant. C., \& Tilquin, J. (2008). Positive emotion as a leading to religion and spirituality. The Journal of Positive Psychology, 3(3), 165-173.

Sarwono, J. (2012). Metode Riset Skripsi: Pendekatan Kuantitatif (menggunakan prosedur SPSS). Jakarta: Elex Media Komputindo.

Sugiyono. (2010). Metode Penelitian Kuantitatif, Kualitatif, dan $R \& D$. Bandung: Alfabeta. 
Underwood, L. G., \& Teresi, J. (2002). The Daily Spiritual Experience Scale: Development, theoretical description, reliability, exploratory factor analysis, and preliminary construct validity using health related data. Annals of Behavioral Medicine, 24, 22-3.

Wood, A. M., Maltby, J., Stewart, N., \& Joseph, S. (2008). Conceptualizing gratitude and appreciation as a unitary personality trait. Personality and Individual Differences, 44, 619-630. 